\title{
Correlation between climate data and land altitude for Fasciola hepatica infection in cattle in Santa Catarina, Brazil
}

\author{
Correlação entre clima e altitude para determinar a infecção de Fasciola \\ hepatica em bovinos em Santa Catarina, Brasil
}

\author{
Ana Elisa Pereira Silva'; Corina da Costa Freitas²; Luciano Vieira Dutra²; Marcelo Beltrão Molento3* (D) \\ ${ }^{1}$ Divisão de Sensoramento Remoto, Instituto Nacional de Pesquisas Espaciais, São José dos Campos, SP, Brasil \\ ${ }^{2}$ Divisão de Processamento de Imagens, Instituto Nacional de Pesquisas Espaciais, São José dos Campos, SP, Brasil \\ ${ }^{3}$ Laboratório de Parasitologia Clínica Veterinária, Departamento de Medicina Veterinária, Universidade Federal do Paraná, Curitiba, PR, Brasil
}

How to cite: Silva AEP, Freitas CC, Dutra LV, Molento MB. Correlation between climate data and land altitude for Fasciola hepatica infection in cattle in Santa Catarina, Brazil. Braz J Vet Parasitol 2020; 29(3): e008520. https://doi.org/10.1590/S1984-29612020065

\begin{abstract}
Fascioliasis is a food-borne parasitic disease that affects a range of animals, including humans caused by Fasciola hepatica. The present study aimed to determine the spatial distribution of bovine fasciolosis and to assess the correlation between the high Positivity Index (PI) and climate data and land altitude, from 2004 to 2008 and 2010 in Santa Catarina (SC), Brazil. Condemned livers of slaughtered animals were obtained from 198 out of 293 municipalities and from 518.635 animals, exclusively from SC. There was a statistically significant difference $(P<0.001)$ between the prevalence of $F$. hepatica and land altitude $\left(\hat{\rho}_{s}=-0.43\right)$. The highest PI (above $\left.10.1 \%\right)$ was observed in cities at 500 to $600 \mathrm{~m}\left(P<0.01 ; \hat{\rho}_{s}=-0.47\right)$ of altitude. There was no correlation between fascioliasis and rainfall in SC. It was determined that weather conditions in the past decade did not impose any limitation to the occurrence of the parasite, making it a disease of permanent clinical importance. These findings are essential to regions with similar geographical and climate conditions (i.e. altitude), when considering long-term control measurements, where animals and humans can be infected.
\end{abstract}

Keywords: Fascioliasis, ruminants, epidemiology, land altitude, precipitation.

\begin{abstract}
Resumo
A fasciolose é uma doença parasitária que afeta uma gama de animais, incluindo humanos, causada por Fasciola hepatica no Brasil. Este estudo teve o objetivo de determinar a distribuição espacial da fasciolose e conferir a correlação do alto índice de positividade (PI), com os dados de clima e altitude, entre 2004 a 2008 e 2010 em Santa Catarina (SC), Brasil. Foram obtidos fígados em frigoríficos de SC, de 518.635 animais de 198 municípios, de um total de 293. Houve diferença estatística significativa $(P<0,001)$ entre a prevalência de $F$. hepatica e a altitude $\left(\hat{\rho}_{s}=-0,43\right)$. O maior PI (acima de 10,1\%) foi observado em municípios de 500 a $600 \mathrm{~m}\left(P<0,01 ; \hat{\rho}_{s}=-0,47\right)$ de altitude. Não foi observada correlação entre fígados parasitados e pluviosidade em SC. Foi observado que os dados climáticos na ultima década não apresentaram limitação para a ocorrência do parasito, fazendo com que o desafio clinico da infecção tenha sido permanente. Os dados são importantes para locais com condições geográficas e climáticas semelhantes (ex. altitude), para considerar medidas de controle a longo prazo, nas quais animais e humanos poderão ser infectados.
\end{abstract}

Palavras-chave: Fasciolose, ruminantes, epidemiologia, altitude, precipitação.

\section{Introduction}

Fasciola hepatica is a Trematode parasite that occur in all regions of Brazil (Aleixo et al., 2015). Fascioliasis, is a classical food-borne anthropozoonotic disease that affects human and domestic and wild animals' (sheep, cattle, horses and other herbivorous) hepatic tissues. The metacercariae is ingested during feeding when animals are 
pasturing or humans eat contaminated vegetables or water (Toledo et al., 2012). Fascioliasis is considered to be endemic in many countries of Latin America (Carmona \& Tort, 2017; Pritsch et al., 2019a), and occurs mainly in livestock in the South of Brazil (Bennema et al., 2014).

The importance of studying fascioliasis is justified by its great impact in animal welfare and the economic losses of approximately US $\$ 3$ billion/year, caused by discarded livers and weight reduction of animal carcasses (Charlier et al., 2014). Among the Brazilian states where $F$. hepatica was determined, the negative impact may reach a staggering figure of US\$210 million/year (Molento et al., 2018), where Rio Grande do Sul (RS) presented the greatest loss of US\$147.4 million/year, followed by Santa Catarina (SC) with US\$24.6 million/year.

The prevalence of the disease is related to environmental conditions, which favors the proliferation of both - the etiologic agent and the intermediate host, the mollusk of the Lymnaeidae family (Dutra et al., 2010; Jiménez-Rocha et al., 2017). Although Pseudosuccinea columella is the most common species found in SC, Galba viatrix was found in two municipalities and Lymnaea rupestris was also described in one site (Medeiros et al., 2014). Some factors that provide favorable habitat to the species are present in the region such as, low altitude, flat terrain, and temperate climate with long summer rains. Altitude is an important variable approached in epidemiological studies of F. hepatica (Malone et al., 1998; McCann et al., 2010), as well as, the level of precipitation (Ducheyne et al., 2015; Selemetas et al., 2014). The latest being an indispensable condition for the parasite's life cycle (Bennema et al., 2014, 2017).

The use of remote sensing technology, associated with the Geographic Information System (GIS), has been important for the analysis of disease prevalence, correlating climatic and environmental data to study relevant epidemiological variations. The GIS information can help proposing sanitary policies to public health and control strategies for both humans and non-human animals (Aleixo et al., 2015; Malone et al., 1998). The products developed from GIS and satellite information to study different diseases concentrate on vector mapping; as disease propagation studies use relative and historical environmental variables (Côrrea, 2007). Dutra et al. (2010), studied the spatial distribution of bovine fascioliasis in the most Southern States of Brazil, RS, SC and Paraná (PR), between 2003 and 2008. The authors found highly endemic areas in RS and SC with disease prevalence of above $40 \%$ in some municipalities. The present study had the aim to correlate the spatial distribution of high positivity index of bovine fascioliasis with rainfall and land altitude in SC, Brazil. The data was collected exclusively from animals that were from SC, which may be slightly different from the data reported by Dutra et al. (2010).

\section{Material and Methods}

The state of SC is located in the South region of Brazil (Figure 1). The climate is Cfa, along the cost of SC, with subtropical and hot and humid summers; and $c f b$, in the central part of the state, characterized by mild summers, according to Koppen-Geiger (Peel et al., 2007) and subjected to variations due to the regional landscape. Data for the infected animals were obtained, exclusively from SC, from 2004 to 2008 and 2010, from the Federal Meat Inspection Service of the Agricultural, Livestock, and Supply Ministry (SIF/MAPA), located in SC. This inclusion criteria is important to mention as the SIF/MAPA sometimes have data from animals that are transported from outside of the state (mainly from RS), but slaughtered in SC. The year of 2009 was not included in this study, due to data inconsistency. The proportion of infected animals (NI) per slaughtered animals (NS), from each municipality was named. The disease positivity index (PI) was calculated according to the formula:

$P I=(N I / N S) \times 100$

Slaughtered animals PI were divided into groups of low (0.1-5\%), intermediate (5.1-10\%) and high (>10.1\%) positivity index (Guimarães et al., 2013).

\section{Data mining and statistical analysis}

Altitude data were acquired from the Topodata Project of the Brazilian Geomorphological Database, which offers products for the Brazilian territory, devised from the Shuttle Radar Topographic Mission (SRTM), and available from the United States Geological Survey (USGS). Shapefiles were used to calculate the mean altitude for each municipality, which was also related to the PI for F. hepatica. 


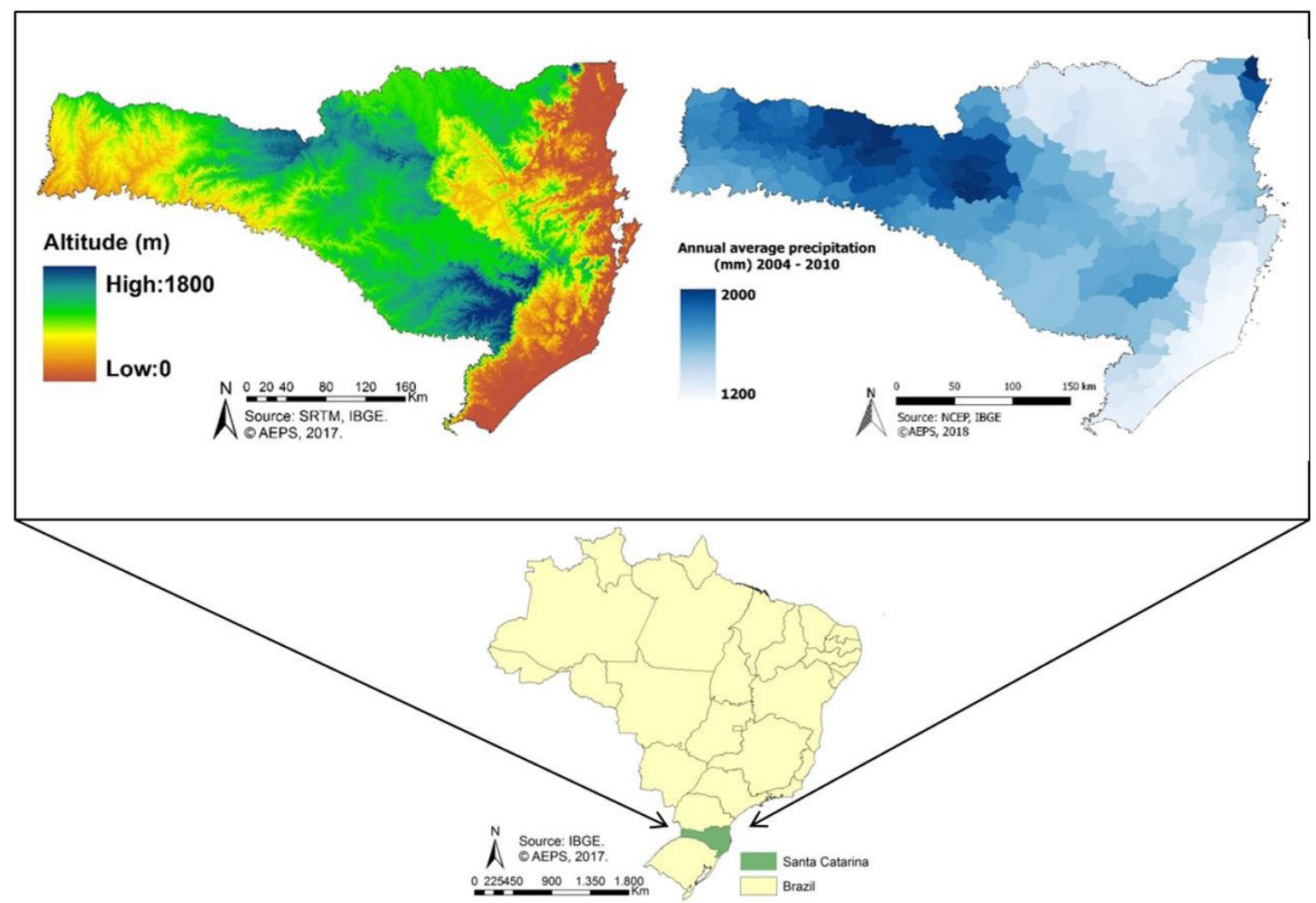

Figure 1. Location of the State of Santa Catarina in Brazil: land altitude and annual average precipitation.

Precipitation data were obtained from the Global Forecast System analyses, which is a weather forecast numerical model produced by the National Center for Environmental Prediction (NCEP), of the National Oceanic and Atmospheric Administration (NOAA - Maryland, USA). The information came from a 15-km spatial resolution data. A 3-hourly data was accumulated to obtain the annual precipitation ( $\mathrm{mm}$ ) to each municipality of SC.

Altitude variables and precipitation were obtained and analyzed for the municipalities with a high PI of F. hepatica. The Spearman correlation coefficient $\left(\hat{\rho}_{s}\right)$ was applied between high PI of fasciolosis and the altitude of the terrain and the accumulated precipitation in 198 cities using Excel (Microsoft, Madison, USA).

\section{Results}

From the data of 2004 to 2008 and 2010, 198 municipalities had animals sent to the Federal Inspection slaughterhouses based in SC. The prevalence of condemned livers due to F. hepatica was 8.8\% (24.455/518.635) for the entire state. The mean infection rate (\%) in the high, intermediate and low PI groups and the number of municipalities with cases in each year are presented in Table 1. The spatial distribution of infected animals in SC is presented in municipal Maps per year in Figure 2.

The most Eastern part of the state has a lower altitude (466 m vs $648 \mathrm{~m}$ ) and a lower rainfall rate $(1.637 \mathrm{~mm}$ vs $1.833 \mathrm{~mm}$ ), comparing to the West (Figure 1). To evaluate the importance of altitude and precipitation in the prevalence of $F$. hepatica in SC, these variables were correlated with high $\mathrm{PI}$ cities. It was observed that high PI municipalities presented an average altitude of $429 \mathrm{~m}$, ranging from 12 to $1.154 \mathrm{~m}$ and an average accumulated precipitation of $1.577 \mathrm{~mm} /$ year, (from 951 to $2.586 \mathrm{~mm} /$ year), during the evaluated period. The results of these correlations are shown in Figure 3.

A medium negative coefficient of correlation of 0.43 (Figure 3a) was found between high PI areas and altitude with a statistically significant difference $(P<0.001)$. Although the results did not present a high correlation, it was observed that the highest rates of the disease occurred in cities in the lowest altitude.

When the correlation between PI and altitude at each $100 \mathrm{~m}$ was analyzed, high rates of the disease were found in municipalities located between 500 and $600 \mathrm{~m}$, with a positive coefficient of correlation of $0.47(P=0.01)$. This was the highest value found among altitude with statistical difference (data not shown). Between 300 and $400 \mathrm{~m}$, 
Table 1. Mean positivity index (PI\%) of Fasciola hepatica, according to high, medium and low PI groups per year and the number of municipalities (n) of Santa Catarina, Brazil.

\begin{tabular}{|c|c|c|c|c|c|c|c|}
\hline \multirow{2}{*}{ Period/Year } & \multicolumn{2}{|c|}{ High PI } & \multicolumn{2}{|c|}{ Intermediate PI } & \multicolumn{2}{|c|}{ Low PI } & \multirow{2}{*}{$\begin{array}{c}\text { Municipalities } \\
\text { Total }\end{array}$} \\
\hline & $\%$ & $\mathbf{n}$ & $\%$ & $\mathbf{n}$ & $\%$ & $\mathbf{n}$ & \\
\hline 2004 & 24.6 & 34 & 6.9 & 24 & 2.0 & 64 & 122 \\
\hline 2005 & 32.0 & 37 & 7.2 & 15 & 1.7 & 80 & 132 \\
\hline 2006 & 21.6 & 35 & 7.3 & 24 & 1.7 & 73 & 132 \\
\hline 2007 & 22.5 & 27 & 6.6 & 27 & 2.2 & 61 & 115 \\
\hline 2008 & 25.0 & 25 & 7.6 & 6 & 1.5 & 67 & 98 \\
\hline 2010 & 13.4 & 2 & 9.0 & $1^{*}$ & 1.0 & $1^{*}$ & 4 \\
\hline Mean/Total & 23.2 & 160 & 7.4 & 97 & 1.7 & 346 & 603 \\
\hline
\end{tabular}

*Absolute value of the only municipality in the group for the year.

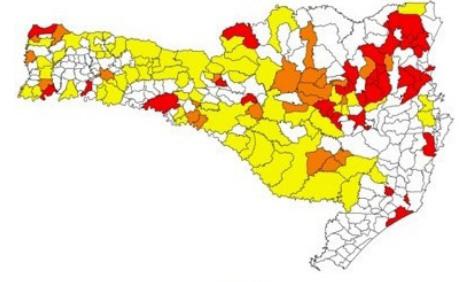

2004

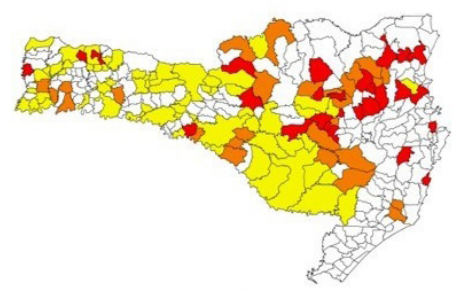

2007

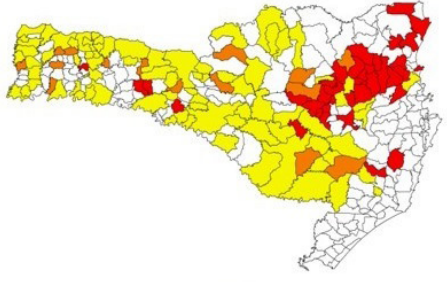

2005

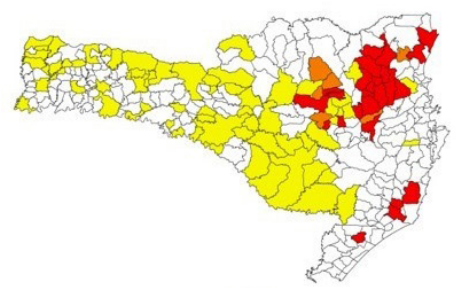

2008

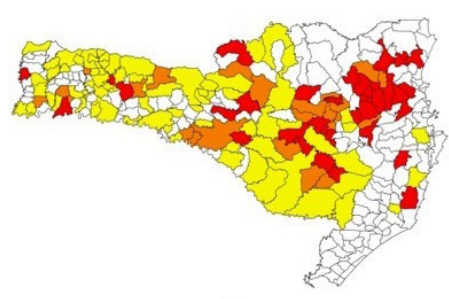

2006

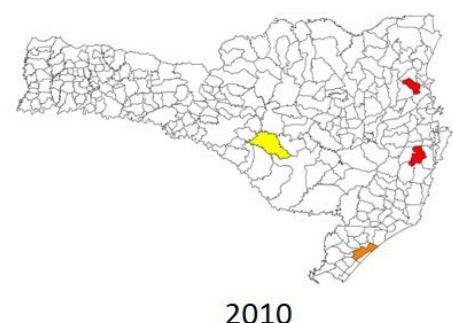

2010

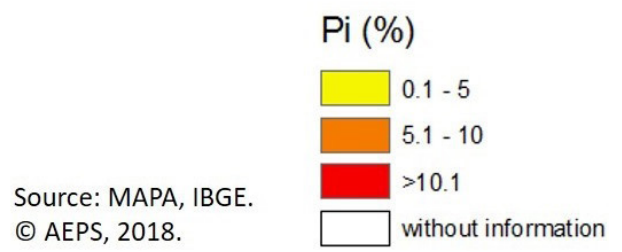

Figure 2. Distribution of high, intermediate, and low Positivity Index (PI) of Fasciola hepatica in cattle over the years in Santa Catarina, Brazil.
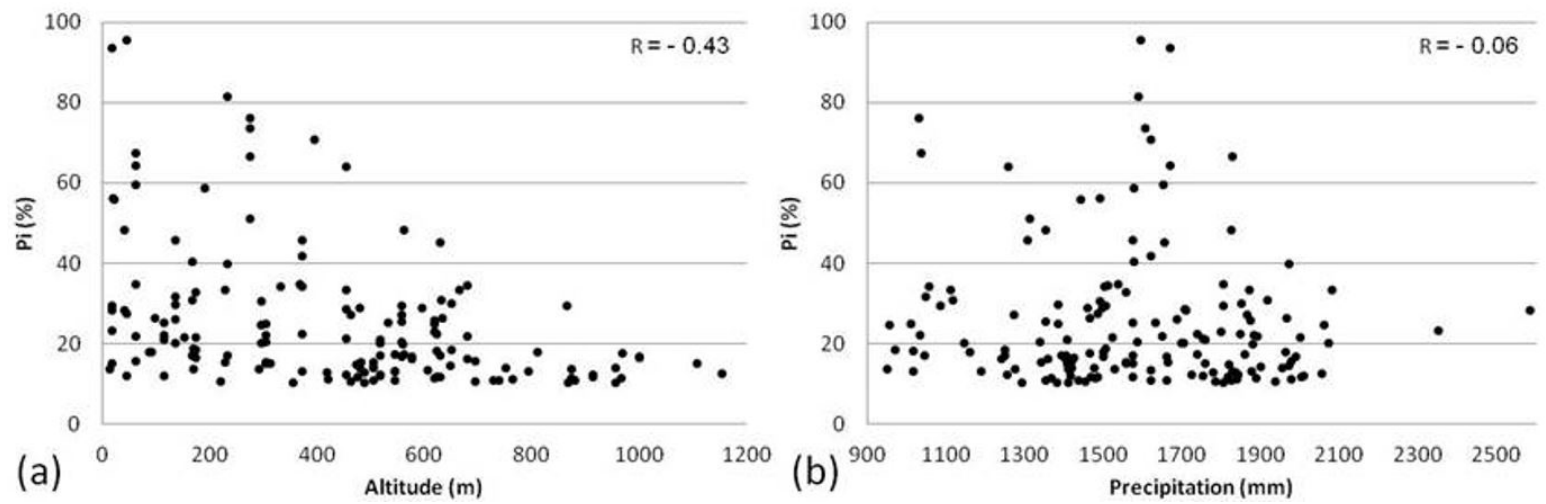

Figure 3. Coefficient of correlation (R) between high Positivity Index (PI) of fasciolosis and (a) altitude of the terrain and (b) the accumulated precipitation in 198 cities of Santa Catarina, Brazil. 
a higher correlation $\left(\hat{\rho}_{s}=0.49\right)$ was obtained; however, no statistical significance $(P=0.06)$ was detected at this altitude. There was no correlation ( $\hat{\rho}_{s}=-0.06, P=0.5$ ), between rainfall and the occurrence of $F$. hepatica (Figure $3 b$ ), possibly due to an above-the-limit of rain for the parasite's life cycle.

\section{Discussion}

The cattle population of SC is approximately 4.5 million animals and although cattle ranches are distributed along the entire state, the largest population is seen in the Central (highland area) and West (lowland area) regions (IBGE, 2006). We reported that the highest correlation between high PI and altitude was found in municipalities located between 500 and $600 \mathrm{~m}$. It was also found that more than $70 \%$ of the high PI for F. hepatica where within the basin of the Itapocú and Itajaí-Açu rivers. The area comprises more than 30 municipalities, having around $34 \%$ of the total cattle herd of SC (IBGE, 2006). The hot and humid weather along the years confirms the conditions that are suitable for the development of the intermediate host, representing an important factor for the high PI of the disease.

In fact, the relationship between the prevalence of $F$. hepatica cases and altitude in this study can be related to local temperatures. The coastal region of SC had the highest temperatures and $F$. hepatica was present in most of the Northern Coast extension (see special distribution Maps). Likewise, Malone et al. (1998), reported that in tropical zones, the best temperature conditions for the development of $F$. hepatica are usually found in low altitude areas. As seen in some parts of South America and Africa, F. hepatica was found up to $1200 \mathrm{~m}$ above sea level, depending on local temperatures (Yilma \& Malone, 1998; Raunelli \& Gonzalez, 2009; Martins et al., 2014; Bennema et al., 2017).

The data from the MAPA/SIF for animals exclusively from SC, showed that most of the municipalities (56\%) with high PI for fascioliasis were at approximately 500 to $600 \mathrm{~m}$ altitude. In RS, just South of SC, a study using multiple linear regression methods was carried out based on F. hepatica bovine infected livers from 2003 to 2010. Among the environmental and climatic variables, altitude was considered the most important factor (Beta coefficient $=-0.263$ ), i.e., inversely proportional to the disease (Silva et al., 2016). Freitas et al. (2014), generated a bioclimatic map for the state of Espírito Santo (ES), in the Southeast of Brazil. The authors showed that altitudes of 0 to $500 \mathrm{~m}$, temperature from 15 to $25^{\circ} \mathrm{C}$, terrain declivity of up to $10 \%$, and accumulated rain between 1.000 and $2.500 \mathrm{~mm} /$ year, where favorable factors for the development of $F$. hepatica and its intermediate host.

Even though in SC, $97.5 \%$ of the municipalities that presented high rates of fasciolosis recorded high annual accumulated rainfall, a favorable condition to fasciolosis (Malone et al., 1998; Freitas et al., 2014), the data did not determine any correlation to this risk factor. This is also in agreement with Silva et al. (2016), using a multiple regression model to study the presence of $F$. hepatica in RS, where the authors did not find any relation between fasciolosis in cattle and rainfall. Maure et al. (1998), studied climate variables and demonstrated that high temperature periods accompanied a decline in the mollusk population in São Paulo, Brazil. The authors also stated that, an increase in rain volume and number of rainy days may damage the mitigating effect of high temperatures in the proliferation of $F$. hepatica intermediate hosts. The data from Sao Paulo showed that regional climate (temperature and rain) variations along the year influenced the presence of the snails, having a great impact on the incidence of the disease. It is worth to mention that the area of São Paulo has frequent dry seasons, which are not common to SC. In another study carried out from 2010 to 2013 in Espirito Santo, reported two annual peaks of L. columella population. The increase in snail numbers was observed in March (2011 and 2013) and in November (2012), when precipitation was above the average (200 mm/year) - suggesting an increase in disease transmission (D'Almeida et al., 2016). Even though pluviosity is an indispensable condition for F. hepatica's life cycle, we demonstrate that the accumulated rain in SC was above the threshold to threaten the prevalence of the disease.

In the current study, the state of SC presented a high prevalence of $F$. hepatica, which was facilitated by the wide geographical distribution of cattle and the mollusk, and its favorable climate. For the study period, the Eastern part of the state was considered highly endemic for bovine fasciolosis, having 20.018 out of 24.455 cases of the disease. The financial impact of fascioliasis to SC was measured by Molento et al. (2018), where the authors reported that the disease accounted for a loss of US $\$ 24.6$ million/year to local economy. Fascioliasis is also a neglected human disease in Brazil, but new cases were recently described in the city of Joinville, the largest city in the North coast of SC (Pritsch et al., 2019b). Associated to that, the most populated cities of SC are located along its Costal area, indicating that there are favorable conditions for more human cases in the future. Therefore, we believe that the environmental conditions, the overlap of large cattle numbers and urban areas, and the continuous presence of the intermediate host are comparable to other risk areas of most the endemic countries (Mas-Coma, 2004). 
The present data demonstrates no epidemiological seasonal or yearly pattern for the disease in SC, indicating a year-long parasite problem, requiring systematic official liver inspection, clinical diagnostic and treatments. But although farmers treat their animals in a regular base (M. Molento, personal information), infections levels are still high. Triclabendazole resistant has not been reported in SC, as in other regions (Brockwell et al., 2014; Ortiz et al., 2013), including in Parana, Brazil (Oliveira et al., 2008), so the chemical control of the disease is still a viable option. More studies are required to correlate local conditions, farm management, and drug use - as well as drug efficacy test, to better understand the dynamic of the disease and its outcome. The association of data from GIS models, special distribution and weather report have attempted to determine a single environmental risk factor for fascioliasis, but the parasite has multiple opportunities to develop, and should be tackled as a complex and dynamic problem. It is also critical to implement long-term control measurements, such as regular diagnostic exams (coproparasitological and immunological tests), strategic treatments, reduce host-parasite (metacercaria) contact, and the data from the Meat Inspection Services MAPA/SIF, for an effective reduction of $F$. hepatica infection in livestock.

\section{Conclusions}

The data revealed that the entire state of SC had an endemic prevalence of $F$. hepatica where cattle infection was found in 68\% (198/293) of the municipalities from 2004 to 2008 and in 2010. The disease had an overdispersed distribution along the seasons and years, as weather conditions in the past decade did not impose any limitation to the occurrence of the parasite, making it a disease of permanent clinical importance. Based on the correlation coefficients and the high Pl, it was determined that the prevalence of bovine fascioliasis was more related to land altitude $\left(\hat{\rho}_{s}=-0.43\right)$, and less to the accumulated precipitation, as there were no rain restriction. Therefore, it is recommended that local authorities develop a more detailed control program, based on the two main geographical conditions of SC (i.e. Costal and Central/Mountainous areas). These findings are essential to regions with similar geographical and climate conditions worldwide, that may be suitable for $F$. hepatica infection in animals and humans.

\section{References}

Aleixo MA, Freitas DF, Dutra LH, Malone J, Martins IVF, Molento MB. Fasciola hepatica: epidemiology, perspectives in the diagnostic and the use of geoprocessing systems for prevalence studies. Semina: Ciênc Agrár 2015; 36(3): 1451-1466. http://dx.doi.org/10.5433/1679$0359.2015 \mathrm{v} 36 \mathrm{n} 3 \mathrm{p} 1451$.

Bennema SC, Molento MB, Scholte RG, Carvalho OS, Pritsch I. Modelling the spatial distribution of Fasciola hepatica in bovines using decision tree, logistic regression and GIS query approaches for Brazil. Parasitology 2017; 144(13): 1677-1685. http://dx.doi. org/10.1017/S0031182017000786. PMid:28805164.

Bennema SC, Scholte RGC, Molento MB, Medeiros C, Carvalho OS. Fasciola hepatica in bovines in Brazil: data availability and spatial distribution. Rev Inst Med Trop São Paulo 2014; 56(1): 35-41. http://dx.doi.org/10.1590/S0036-46652014000100005. PMid:24553606.

Brockwell YM, Elliott TP, Anderson GR, Stanton R, Spithill TW, Sangster NC. Confirmation of Fasciola hepatica resistant to triclabendazole in naturally infected Australian beef and dairy cattle. Int J Parasitol Drugs Drug Resist 2014; 4(1): 48-54. http://dx.doi. org/10.1016/j.jpddr.2013.11.005. PMid:24596668.

Carmona C, Tort JF. Fasciolosis in South America: epidemiology and control challenges. J Helminthol 2017; 91(2): 99-109. http:// dx.doi.org/10.1017/S0022149X16000560. PMid:27608827.

Charlier J, Vercruysse J, Morgan E, Van Dijk J, Williams DJL. Recent advances in the diagnosis, impact on production and prediction of Fasciola hepatica in cattle. Parasitology 2014; 141(3): 326-335. http://dx.doi.org/10.1017/S0031182013001662. PMid:24229764.

Corrêa MP. Epidemiologia e Saúde Pública. In: Rudorff BFT, Shimabukuro YE, Ceballos JC. Sensor Modis e Suas Aplicações Ambientas no Brasil. São José dos Campos: Editora Parêntese; 2007. p. 353-362.

D'Almeida SCG, Freitas DF, Carneiro MB, Camargo PF, Azevedo JC, Martins IV. The population density of Lymnaea columella (Say, 1817) (Mollusca, Lymnaeidae) an intermediate host of Fasciola hepatica (Linnaeus, 1758), in the Caparaó microregion, ES, Brazil. Braz J Biol 2016; 76(2): 334-340. http://dx.doi.org/10.1590/1519-6984.14314. PMid:26934156.

Ducheyne E, Charlier J, Vercruysse J, Rinaldi L, Biggeri A, Demeler J, et al. Modelling the spatial distribution of Fasciola hepatica in dairy cattle in Europe. Geospat Health 2015; 9(2): 261-270. http://dx.doi.org/10.4081/gh.2015.348. PMid:25826307.

Dutra LH, Molento MB, Naumann CRC, Biondo AW, Fortes FS, Savio D, et al. Mapping risk of bovine fasciolosis in the south of Brazil using Geographic Information Systems. Vet Parasitol 2010; 169(1-2): 76-81. http://dx.doi.org/10.1016/j.vetpar.2009.12.015. PMid:20071083. 
Freitas DF, Martins IVF, Santos GM, Santos AR, Gomes DS. Bioclimatic distribution and prevalence maps for Fasciola hepatica in Espírito Santo State, Brazil. J Venom Anim Toxins Incl Trop Dis 2014; 20(1): 32. http://dx.doi.org/10.1186/1678-9199-20-32. PMid:25101121.

Guimarães RJPS, Freitas CC, Dutra LV, Oliveira G, Carvalho OS. Multiple regression for the Schistosomiasis positivity index estimates in the Minas Gerais State, Brazil at small communities and cities levels. In: El Ridi R, editor. Parasitic Disease - Schistosomiasis. Cairo: IntechOpen; 2013. p. 3-26. http://dx.doi.org/10.5772/53500

Jiménez-Rocha AE, Argüello-Vargas S, Romero-Zuñiga JJ, Sequeira-Avalos JA, Dolz G, Montenegro-Hidalgo V, et al. Environmental factors associated with Dictyocaulus viviparus and Fasciola hepatica prevalence in dairy herds from Costa Rica. Vet Parasitol Reg Stud Rep 2017; 9: 115-121. http://dx.doi.org/10.1016/j.vprsr.2017.06.006. PMid:31014833.

Instituto Brasileiro de Geografia e Estatistica - IBGE Census of Agriculture. [online]. Rio de Janeiro: IBGE; 2006 [cited 2018 Mar 02]. Available from: http://www.ibge.gov.br/home/estatistica/economia/agropecuaria/censoagro/default.shtm

Malone JB, Gommes R, Hansen J, Yilma JM, Slingenberg J, Snijders F, et al. A geographic information system on the potential distribution and abundance of Fasciola hepatica and F. gigantica in east Africa based on Food and Agriculture Organization databases. Vet Parasitol 1998; 78(2): 87-101. http://dx.doi.org/10.1016/S0304-4017(98)00137-X. PMid:9735915.

Martins IVF, Avelar BR, Bernardo CC, Leão AC, Pereira MJS. Distribution of bovine fasciolosis and associated factors in the of south Espírito Santo, Brazil: an update. Braz J Vet Parasito/ 2014; 23(1): 23-29. http://dx.doi.org/10.1590/S1984-29612014003. PMid:24728357.

Mas-Coma S. Human fascioliasis: epidemiological patterns in human endemic areas of South America, Africa and Asia. Southeast Asian J Trop Med Public Health 2004; 35(Suppl 1): 1-11.

Maure EAP, Bustamante M, Serra-Freire NM, Gomes DC. Population dynamic of Lymnaea columella (Say, 1817), intermediate host of Fasciola hepatica (Linnaeus, 1758) in municipalities of the São Paulo State, Brazil. Braz J Vet Res Anim Sci 1998; 35(4): 151-155. http://dx.doi.org/10.1590/S1413-95961998000400001.

McCann CM, Baylis M, Williams DJL. The development of linear regression models using environmental variables to explain the spatial distribution of Fasciola hepatica infection in dairy herds in England and Wales. Int J Parasitol 2010; 40(9): 1021-1028. http:// dx.doi.org/10.1016/j.ijpara.2010.02.009. PMid:20227416.

Medeiros C, Scholte RG, D'Ávila S, Caldeira RL, Carvalho OS. Spatial distribution of Lymnaeidae (Mollusca, Basommatophora), intermediate host of Fasciola hepatica Linnaeus, 1758 (Trematoda, Digenea) in Brazil. Rev Inst Med Trop São Paulo 2014; 56(3): 235252. http://dx.doi.org/10.1590/S0036-46652014000300010. PMid:24879003.

Molento MB, Bennema SA, Bertot J, Pritsch IC, Arenal A. Bovine fascioliasis in Brazil: economic impact and forecasting. Vet Parasitol Reg Stud Rep 2018; 12: 1-3. http://dx.doi.org/10.1016/j.vprsr.2017.12.004. PMid:31014798.

Oliveira DR, Ferreira DM, Stival CC, Romero F, Cavagnolli F, Kloss A, et al. Triclabendazole resistance involving Fasciola hepatica in sheep and goats during an outbreak in Almirante Tamandare, Paraná, Brazil. Braz J Vet Parasitol 2008; 17(Suppl 1): 149-153. PMid:20059835.

Ortiz P, Scarcella S, Cerna C, Rosales C, Cabrera M, Guzmán M, et al. Resistance of Fasciola hepatica against triclabendazole in cattle in Cajamarca (Peru): a clinical trial and in vivo efficacy test in sheep. Vet Parasito/ 2013; 195(1-2): 118-121. http://dx.doi.org/10.1016/j. vetpar.2013.01.001. PMid:23352107.

Peel MC, Finlayson BL, McMahon TA. Updated world map of the Köppen-Geiger climate classification. Hydrol Earth Syst Sci 2007; 11(5): 1633-1644. http://dx.doi.org/10.1029/2006GL028098

Pritsch IC, Garcia RL, Douat D, Schwendler RR, Buttendorf MRB, Molento MB. First reported case of clinical fascioliasis in Santa Catarina, Brazil. Rev Soc Bras Med Trop 2019b; 52: e20190070. http://dx.doi.org/10.1590/0037-8682-0070-2019. PMid:31340366.

Pritsch IC, Stanula ECA, dos Anjos A, Bertor JA, Molento MB. Fascioliasis in buffaloes: A 5-year forecast analysis of the disease based on a 15-year survey in Brazil. Braz J Vet Parasito/ 2019a; 28(3): 410-415. http://dx.doi.org/10.1590/s1984-29612019040. PMid:31340249.

Raunelli F, Gonzalez S. Strategic control and prevalence of Fasciola hepatica in Cajamarca, Peru: A pilot study. Int J Appl Res Vet Med 2009; 7(4): 145-152.

Selemetas N, Phelan P, O'Kiely PP, de Waal T. Weather and soil type affect incidence of fasciolosis in dairy cow herds. Vet Rec 2014; 175(15): 371. http://dx.doi.org/10.1136/vr.102437. PMid:25124886.

Silva AEP, Freitas CC, Dutra LV, Molento MB. Assessing the risk of bovine fasciolosis using linear regression analysis for the state of Rio Grande do Sul, Brazil. Vet Parasitol 2016; 217: 7-13. http://dx.doi.org/10.1016/j.vetpar.2015.12.021. PMid:26827853.

Toledo R, Esteban JG, Fried B. Current status of food-borne trematode infections. Eur J Clin Microbiol Infect Dis 2012; 31(8): 17051718. http://dx.doi.org/10.1007/s10096-011-1515-4. PMid:22228314.

Yilma JM, Malone JB. A geographic information system forecast model for strategic control of fasciolosis in Ethiopia. Vet Parasitol 1998; 78(2): 103-127. http://dx.doi.org/10.1016/S0304-4017(98)00136-8. PMid:9735916. 